\title{
Yacon Flour and Corn Steep Liquor as Substrates for Inulinase and Biomass Production by Kluyveromyces marxianus NRRL Y-7571
}

\section{Leonardo de Amorin Sathler ${ }^{1}$, Jonas Contiero ${ }^{2}$, Marcia Luciana Cazetta ${ }^{3}$}

${ }^{1}$ Agricultural, Environmental and Biological Center, Federal University of Recôncavo da Bahia. Cruz das Almas, Bahia, Brazil.

Leonardo.sathler@ufv.br

${ }^{2}$ Biochemistry and Microbiology Department, Bioscience Institute, São Paulo State University -UNESP. Rio Claro, São Paulo, Brazil.

jconti@rc.unesp.br

${ }^{3}$ Science and Technolgy Center, Federal University of Recôncavo da Bahia. Cruz das Almas, Bahia, Brazil. malulz@yahoo.com.br

\section{Correspondent adress:}

${ }^{3}$ Science and Technolgy Center, Federal University of Recôncavo da Bahia. Cruz das Almas, Bahia, Brazil. malulz@yahoo.com.br

\begin{abstract}
Yacon is a perennial plant native of the Andes that stores inulin-type polyfructans as reserve carbohydrates in its tubers. The enzymes that hydrolyze the inulin $\beta-2,1$ fructose linkages are called inulinases and are much used to produce high fructose syrups (HFS) and ethanol. The present study investigated inulinase and biomass production by Kluyveromyces marxianus NRRL Y-7571 using yacon flour as carbon source and corn steep liquor as nitrogen source by a Central Composite Design (CCD) $2^{2}$ to carry out experiments and Surface Response Methodology (RSM) to analyze the results. The maximum enzyme production was $36.1 \mathrm{U} \cdot \mathrm{ml}^{-1}$ and biomass production was $8.95 \mathrm{~g}^{-1} \mathrm{I}^{-1}$ under the condition of $7 \%$ yacon flour and $2 \%$ corn steep liquor. The crude enzyme partial characterization showed that inulinase had optimal pH at 4.0 and optimal temperature at $60^{\circ} \mathrm{C}$. The enzyme maintained over $90 \%$ of its activity for four hours at $45^{\circ} \mathrm{C}$ and $50^{\circ} \mathrm{C}$.
\end{abstract}

\section{Indexing terms/Keywords}

Enzyme; yeast; Surface Response Methodology; agro-industrial substrates

\section{Academic Discipline And Sub-Disciplines}

Microbiology

\section{Subject Classification}

Biology

Type (Method/ approach)

Quasi-Experimental

\section{Council for Innovative Research}

Peer Review Research Publishing System

\section{Journal: JOURNAL OF ADVANCES IN BIOTECHNOLOGY}

Vol. 4, No. 3

www.ciribt.org , jbteditor@gmail.com 


\section{INTRODUCTION}

Inulin-type polyfructans are linear carbohydrates with $\beta(2 \rightarrow 1)$ bonds between the fructose units. They have received a lot of attention recently due to their functional properties, because they improve food texture and fiber content without altering the appearance and flavor of the end product and they also have a beneficial effect on the intestinal flora and serum parameters due to their non-digestibility [1-4]. Furthermore, they have been used as a renewable raw material to produce several substances of industrial interest, especially high fructose (HFS) syrup and bioethanol [5-8]. Many plants store inulin as reserve carbohydrate, usually in bulbs, tubers or tuberous roots, such as Jerusalem artichoke (Helianthus tuberosus), dahlia (Dahlia pinnata), chicory (Cichoriumendivia), dandelion (Taraxacum officinale) and yacon (Smallanthus sonchifolius) [6, 9]. Of these, yacon has stood out as a functional food because of its fructoologosaccharides (FOS) rich composition.

Yacon is a perennial herb that belongs to the Asteraceae family, which height varies from 1.5 to $3.0 \mathrm{~m}$ and shows a root system composed from 4 to 20 tubercles. It is native to the Andean valleys of Colombia, Ecuador, Peru, Bolivia and northwestern Argentina. In the mid-1980s, yacon cultivation started outside the Andes, at first in New Zealand and Japan, from where it spread to other countries, and can be found since the 1990s in Brazil, Paraguay, United States, Slovakia, China, Korea and Taiwan [10]. This crop was introduced to Brazil in the early 1990s, in the state of São Paulo [11], but consumption became popular only in the mid 2000s, when this tuber became popularly known as "yacon potato" or "diet potato" [12], especially among people with diabetes and consumers of low calorie foods.

Fructooligosaccharides (FOS) are the main reserve carbohydrate of the yacon, in addition to inulin, glucose, fructose and sucrose [9, 13], so that this tuber is an interesting substrate for fermentation processes. The enzymes that hydrolyze linear $\beta-2,1$-linked polyfructose chains such as inulin are called inulinases. These enzymes belong to the hydrolases class, being classified as $\beta-2,1-D$-fructan frutanohydrolases (EC:3.2.1.7) [14-16], and are used to produce high fructose syrups (HFS) by enzymatic hydrolysis of the inulin, although they can also hydrolyses the linkages of other sugars such as sucrose, raffinose and stachyose, with high yield of up to $95 \%$ of the end product [16-18]. Although some bacteria such as Xanthomonas and Streptomyces are reported as good inulinase producers [19-21], fungi are among the most used, especially the Aspergillus genus [17, 22-26]. Among the yeasts, good inulinase productions are reported by the genera Pichia [11, 27] and Saccharomyces [28], but it is the yeasts of the Kluyveromyces genus, especially K. marxianus, that are the most studied and promising [18, 29-32] because of their high production, rapid growth and GRAS (Generally Recognized As Safe) classification [33]. Thus the objective of the present study was to verify the potential of yacon flour as carbon source to inulinase production by $K$. marxianus NRRL Y-7571 using a Central Composite Design (CCD) to carry out the experiments and Response Surface Methodology (RSM) to analyze the results.

\section{MATERIAL AND METHODS}

\section{Obtaining yacon flour}

Yacon tubers were washed with water, cut in thin slices and dried at $65^{\circ} \mathrm{C}$ for 48 hours in a forced air circulation chamber. The dried pieces were ground in a blender until a fine powder was obtained and stored at room temperature.

\section{Microorganism and culture conditions}

The K. marxianus NRRL Y-7571 yeast was acquired from the André Tosello Foundation, Campinas, Brazil (reference 7073). The preinoculum consisted of basal medium containing (\%): sucrose $1, \mathrm{KH}_{2} \mathrm{PO}_{4} 1.5, \mathrm{NH}_{4} \mathrm{Cl} 0.15, \mathrm{KCl} 0.12$, $\mathrm{MgSO}_{4} .7 \mathrm{H}_{2} \mathrm{O} 0.07$ incubated at $37^{\circ} \mathrm{C}$ and $150 \mathrm{rpm}$, for 24 hours. For the inoculum medium, the sucrose was substituted with yacon flour and corn steep liquor.

\section{Experimental designs}

To carry out the experiment, yacon flour $\left(X_{1}\right)$ and corn steep liquor $\left(X_{2}\right)$ were chosen as independent variables. The effects of these variables, and their interactions on inulinase production, were studied by the Central Composite Design (CCD) $2^{2}$, according to Rodrigues and lemma [34]. The dependent variables (responses) were: inulinase (U.ml ${ }^{-1}$ ) and biomass (g. ${ }^{-1}$ ) production. Two CCD were carried out, named Experimental Design 1 and Experimental Design 2. In Experimental Design 1 the yacon flour concentrations ranged from $2 \%$ to $7.8 \%$ and the corn steep liquor concentrations from $8 \%$ to $2.2 \%$ (Table 1) and in Experimental Design 2 the concentrations ranged from $5.5 \%$ to $8.5 \%$ for yacon flour and from $1.3 \%$ to $2.7 \%$ for corn steep liquor (Table 4). Submerged fermentations were carried out in Erlenmeyer flasks containing $30 \mathrm{ml}$ culture medium with initial $\mathrm{pH}$ adjusted to 5.0 with orthophosphoric acid at $150 \mathrm{rpm}$ and $37^{\circ} \mathrm{C}$ for 96 hours, inoculated with $10 \%$ $(\mathrm{v} / \mathrm{v})$ inoculum.

Two levels were chosen, upper $(+1)$ and lower $(-1)$ in addition to another central point $(0)$, which was applied in triplicates to determine the rigor of the methodology, plus two axial points $(+1.41$ and -1.41$)$ to use the quadratic model and obtain a surface-response. This model is represented by a second order polynomial regression as Eq. (1):

$$
Y=b_{0}+b_{1} X_{1}+b_{2} X_{2}+b_{11} X_{1}^{2}+b_{22} X_{2}^{2}+b_{12} X_{1} X_{2}
$$

Where $y$ is the predicted response; $X_{1}$ and $X_{2}$ are the codified independent variables (yacon flour extract and corn steep liquor, respectively); $b_{0}$ is the point of intersection; $b_{1}$ and $b_{2}$ are linear coefficients; $b_{12}$ double interaction coefficient; $b_{11}$ 
and $b_{22}$ are quadratic coefficients. The effects of the variables and their interactions on the analyzed responses were estimated using the STATISTICA 7.0® (StatSoft), considering $5 \%$ level of significance. The statistical parameters were estimated by analysis of variance (ANOVA) considering the Fisher's test, and the quality of the fit of the quadratic model was expressed by the coefficient of correlation $\left(R^{2}\right)$.

\section{Cell growth}

Biomass was determined through turbidimetry with a spectrophotometer at $\lambda=600 \mathrm{~nm}$. Biomass $\left(\mathrm{g} . \mathrm{I}^{-1}\right)$ was calculated by the correlation between dry cell weight and optic density (OD) to a standard curve. All experiments were conduced in triplicate.

\section{Enzymatic activity}

The enzymatic activity of the supernatant was determined according to Suzuki et al. [35] through the determination of reducing sugars formed by incubation of the $1 \mathrm{~mL}$ of enzyme in sucrose $2 \%$, citrate-phosphate buffer $0.05 \mathrm{M} \mathrm{with} \mathrm{pH} \mathrm{4.0,}$

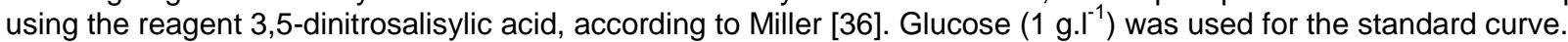

\section{Crude enzyme partial characterization}

Optimum $\mathrm{pH}$ was obtained by determining the enzymatic activity of the supernatant at different $\mathrm{pH}$ values, using the following buffers (0.05M): Glycine- $\mathrm{HCl}(\mathrm{pH} 2-3)$, sodium citrate buffer $(\mathrm{pH} 3-6)$, phosphate buffer ( $\mathrm{pH}$ 6-8), Tris- $\mathrm{HCl}$ buffer (pH 8-9), Glycine-NaOH (pH 9-11). The optimum temperature was obtained by determining the enzymatic activity at different temperatures, ranging from $45^{\circ} \mathrm{C}$ to $60^{\circ} \mathrm{C}$. The enzyme thermal stability was assessed by incubating the enzyme at $45^{\circ} \mathrm{C}$ and $60^{\circ} \mathrm{C}$ for five hours.

\section{RESULTS}

\section{Experimental design 1}

Table 1 shows the responses obtained when yacon flour concentrations ranged from $2.0 \%$ to $7.8 \%$ and corn steep liquor concentrations from $0.8 \%$ and $2.5 \%$. The greatest inulinase $\left(31.0 \mathrm{U} \cdot \mathrm{ml}^{-1}\right)$ and biomass productions $\left(7.69 \mathrm{~g} . \mathrm{I}^{-1}\right)$ occurred on run 4 , with $7 \%$ yacon flour and $2 \%$ corn steep liquor.

Table 1. Matrix of experimental design 1 with responses (inulinase production, $\mathrm{U}^{\mathrm{ml}}{ }^{-1}$ and biomass production, g. I $^{-1}$ )

\begin{tabular}{|c|c|c|c|c|c|c|c|c|}
\hline & \multicolumn{2}{|c|}{ Variables } & \multicolumn{2}{|c|}{ Observed } & \multicolumn{4}{|c|}{ Predicted } \\
\hline & & & $\begin{array}{c}\text { Enzymatic } \\
\text { activity }\end{array}$ & Biomas: & & $\begin{array}{l}\text { nzymatic } \\
\text { activity }\end{array}$ & & 3iomass \\
\hline Runs & $\mathbf{X}_{1}$ & $\mathbf{X}_{2}$ & $\left(\mathrm{U} . \mathrm{ml}^{-1}\right)$ & $\left(\mathbf{g} . I^{-1}\right)$ & & $\left(\right.$ U.ml $\left.l^{-1}\right)$ & & $\left(g . I^{-1}\right)$ \\
\hline 1 & -1 & -1 & 10.0 & 5.75 & & 8.84 & & 5.54 \\
\hline 2 & 1 & -1 & 25.7 & 5.79 & & 25.9 & & 5.70 \\
\hline 3 & -1 & 1 & 14.0 & 5.69 & & 13.3 & & 5.59 \\
\hline 4 & 1 & 1 & 31.0 & 7.69 & & 31.7 & & 7.70 \\
\hline 5 & -1.41 & 0 & 3.0 & 5.08 & & 4.16 & & 5.25 \\
\hline 6 & 1.41 & 0 & 30.0 & 6.86 & & 29.2 & & 6.86 \\
\hline 7 & 0 & -1.41 & 19.0 & 5.33 & & 19.5 & & 5.49 \\
\hline 8 & 0 & 1.41 & 27.1 & 6.94 & & 26.9 & & 6.95 \\
\hline 9 & 0 & 0 & 26.6 & 6.21 & & 24.4 & & 6.11 \\
\hline 10 & 0 & 0 & 21.6 & 6.11 & & 24.4 & & 6.11 \\
\hline \multirow[t]{3}{*}{11} & 0 & 0 & 25.2 & 6.01 & & 24.4 & & 6.11 \\
\hline & & & & \multicolumn{5}{|c|}{ Real Levels } \\
\hline & & & & -1.41 & -1 & 0 & +1 & +1.41 \\
\hline $\mathrm{X}_{1}$ & \multicolumn{3}{|c|}{ Yacon flour (\%) } & 2.0 & 3.0 & 5.0 & 7.0 & 7.8 \\
\hline $\mathrm{X}$ & \multicolumn{3}{|c|}{ Corn Steep Liquor (CSL) (\%) } & 0.8 & 1.0 & 1.5 & 2.0 & 2.2 \\
\hline
\end{tabular}


The statistical analyses indicated that the yacon flour variable $\left(X_{1}\right)$ had a significant effect $(p<0.05)$ on inulinase production in the linear $(L)$ and quadratic $(Q)$ terms of the model, but only had positive influence on the linear term. This means that the increase in the yacon flour concentration to $7.0 \%$ lead to an increase in inulinase production (Fig. 1a).

The interaction among the variables also had a positive but not significant effect $(p<0.05)$ as shown by the regression coefficients (Table 2). It can be observed that the greatest enzymatic productions were found in the experiments with the highest concentrations of the carbon source (runs 2, 4, 6, 8, 9, 10 and 11) while in the experiments with the lower yacon flour concentration, between $2.0 \%$ and $3.0 \%$ (runs 1, 3 and 5), the enzymatic activity decreased progressively, reaching $3.0\left(\right.$ U. $\mathrm{ml}^{-1}$ ) in run 5 (Table 1).

Corn steep liquor $\left(X_{2}\right)$ had no statistically significant influence in the concentration range studied $(p<0.05)(T a b l e 2)$. However, Fig. 1a shows that increase in the concentration of the nitrogen source positively influenced enzyme production.

Table 2. Regression coefficient of inulinase production

\begin{tabular}{|l|c|c|c|c|}
\hline & $\begin{array}{c}\text { Regression } \\
\text { coefficient }\end{array}$ & $\begin{array}{c}\text { Standard } \\
\text { error }\end{array}$ & $\mathbf{t}(5)$ & P-value \\
\hline Mean & 24.46667 & 1.094416 & 22.35591 & 0.000003 \\
\hline Yacon flour (\%) (L) & 8.86047 & 0.670190 & 13.22083 & 0.000044 \\
\hline Yacon flour (\%) (Q) & -3.88333 & 0.797686 & -4.86825 & 0.004600 \\
\hline CSL (\%) (L) & 2.59439 & 0.670190 & 3.87113 & 0.011747 \\
\hline CSL (\%) (Q) & -0.60833 & 0.797686 & -0.76262 & 0.480100 \\
\hline Yacon flour x CSL & 0.32500 & 0.947792 & 0.34290 & 0.745618 \\
\hline L: Linear; Q: Quadratic & & & & \\
\hline
\end{tabular}
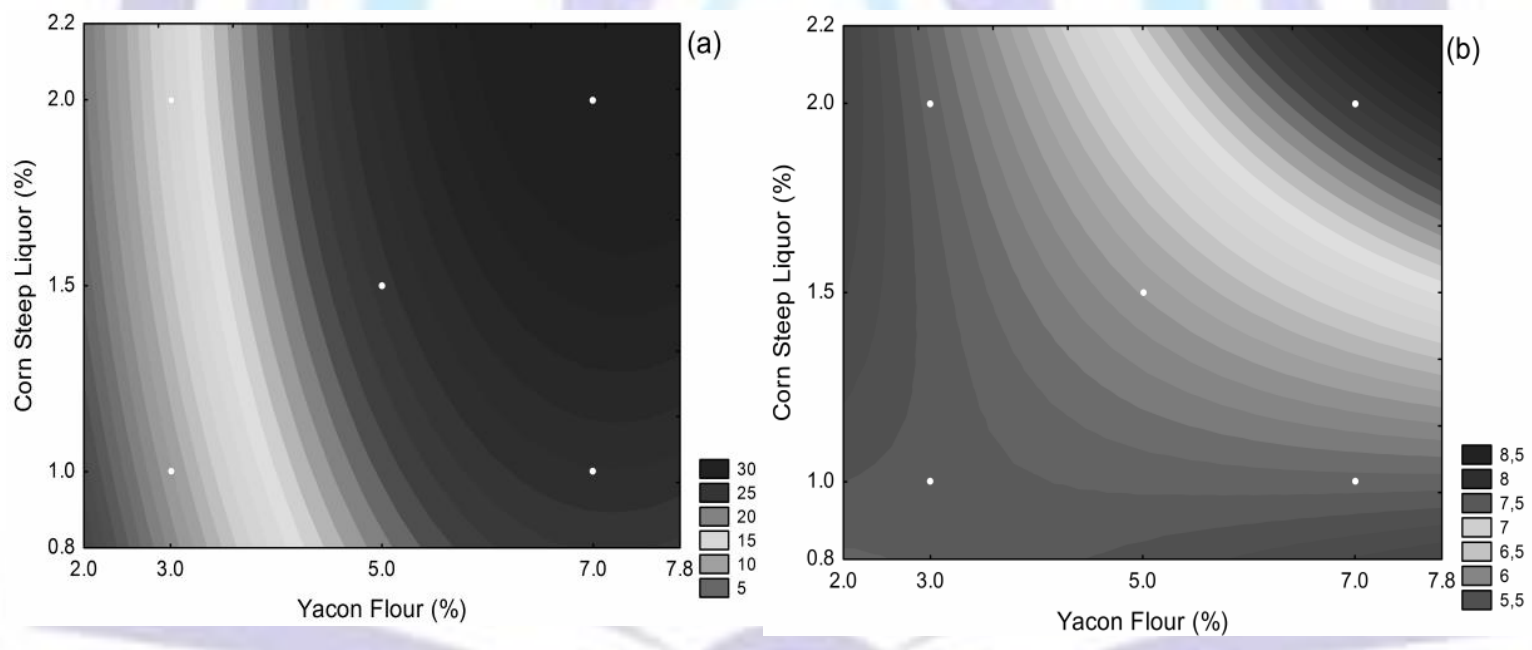

Fig 1. Contour plot from the model equation from experimental design 1 for inulinase production, U.ml ${ }^{-1}$ (a) and biomass production, $g . \mathrm{I}^{-1}$ (b) by $K$. marxianus NRRL Y-7571 in submerged fermentation after 96 hours.

Increase in the concentration of the carbon $\left(X_{1}\right)$ and nitrogen $\left(X_{2}\right)$ sources also had a positive effect on biomass production, although it was less marked than that on the enzyme production and ranged from $5.8 \mathrm{~g} . \mathrm{I}^{-1}$ (run 5 ) to $7.9 \mathrm{g.l}^{-1}$ (run 4). The runs 1, 2, 3, 5 and 7 presented the lowest biomass productions (5.53 g. $\mathrm{I}^{-1}$, on average) at $0.8-2.0 \%$ corn steep liquor concentrations (Table 1). The statistical analysis showed that only linear terms of $X_{1}$ and $X_{2}$ had significant effect $(p<0.05)$ (Table 3). Thus it can be concluded that the increase in the concentrations of $X_{1}$ and $X_{2}$ can lead to increase in biomass production, as shown in Fig. $1 \mathrm{~b}$. 
Table 3. Regression coefficient of biomass

\begin{tabular}{|l|c|c|c|c|}
\hline & $\begin{array}{c}\text { Regression } \\
\text { coefficient }\end{array}$ & $\begin{array}{c}\text { Standard } \\
\text { error }\end{array}$ & $\mathbf{t}(\mathbf{5})$ & P-value \\
\hline Mean & 6.110000 & 0.094990 & 64.32224 & 0.000000 \\
\hline Yacon flour (\%) (L) & 0.569663 & 0.058170 & 9.79314 & 0.000189 \\
\hline Yacon flour (\%) (Q) & -0.025625 & 0.069236 & -0.37011 & 0.726459 \\
\hline CSL (\%) (L) & 0.514610 & 0.058170 & 8.84673 & 0.000307 \\
\hline CSL (\%) (Q) & 0.056875 & 0.069236 & 0.82147 & 0.448761 \\
\hline Yacon flour x CSL & 0.490000 & 0.082264 & 5.95642 & 0.001907 \\
\hline L: Linear; Q: Quadratic & & & & \\
\hline
\end{tabular}

The analysis of variance (ANOVA) showed that the model was statistically significant at $95 \%$ confidence level because the $F$ value was 100.16 for enzyme production and 96.31 for biomass. The coefficients of correlation $\left(R^{2}\right)$ of 0.9771 for inulinase production and 0.9768 for biomass showed that there was an excellent correlation between the observed and predicted values and the model explained about $97.0 \%$ of the results.

\section{Experimental design 2}

A new CCD $2^{2}$ was established taking into account the results from the first experimental design. New concentrations were established (Table 4) in order to find the best conditions for inulinase and biomass production by $K$. marxianus NRRL $Y-7571$. The increase in the $X_{1}$ and $X_{2}$ variables positively influenced both inulinase production and cell growth. The greatest enzyme production (36.1 U.ml ${ }^{-1}$ ) and the greatest biomass production $\left(9.95 \mathrm{~g}^{-1}\right)^{-1}$ occurred in run 8 , with $7.0 \%$ yacon flour and $2.7 \%$ corn steep liquor. This represented an increase of about $14 \%$ in both responses, compared to experimental design 1.

Table 4. Matrix of the experimental design 2 with responses in terms of biomass and inulinase production

\begin{tabular}{|c|c|c|c|c|c|c|c|c|}
\hline \multirow[t]{2}{*}{ Runs } & \multicolumn{2}{|c|}{ Variables } & \multicolumn{2}{|c|}{ Observed values } & \multicolumn{4}{|c|}{ Predicted values } \\
\hline & & & $\begin{array}{c}\text { Enzymatic } \\
\text { activity }\end{array}$ & Biomass & & $\begin{array}{l}\text { Izymatic } \\
\text { Ictivity }\end{array}$ & & Biomass \\
\hline & $\mathbf{X}_{1}$ & $X_{2}$ & $\left(\mathrm{U} . \mathrm{ml}^{-1}\right)$ & $\left(g . I^{-1}\right)$ & & U.ml') & & $\left(g . I^{-1}\right)$ \\
\hline 1 & -1 & -1 & 24.4 & 6.47 & & 23.84 & & 6.30 \\
\hline 2 & 1 & -1 & 22.3 & 5.19 & & 19.62 & & 5.68 \\
\hline 3 & -1 & 1 & 25.3 & 7.91 & & 29.04 & & 7.65 \\
\hline 4 & 1 & 1 & 26.1 & 7.98 & & 27.73 & & 8.39 \\
\hline 5 & -1.41 & 0 & 26.3 & 6.18 & & 24.26 & & 6.52 \\
\hline 6 & 1.41 & 0 & 19.4 & 7.20 & & 20.35 & & 6.60 \\
\hline 7 & 0 & -1.41 & 20.6 & 6.20 & & 23.10 & & 6.01 \\
\hline 8 & 0 & 1.41 & 36.1 & 8.95 & & 32.51 & & 8.88 \\
\hline 9 & 0 & 0 & 29.5 & 8.33 & & 28.23 & & 8.62 \\
\hline 10 & 0 & 0 & 28.1 & 8.93 & & 28.23 & & 8.62 \\
\hline \multirow[t]{3}{*}{11} & 0 & 0 & 27.1 & 8.61 & & 28.23 & & 8.62 \\
\hline & & & & \multicolumn{5}{|c|}{ Real Levels } \\
\hline & & & & -1.41 & -1 & 0 & +1 & +1.41 \\
\hline $\mathrm{X}_{1}$ & \multicolumn{3}{|c|}{ Yacon flour (\%) } & 5.5 & 6 & 7 & 8 & 8.5 \\
\hline $\mathrm{X}_{2}$ & \multicolumn{3}{|c|}{ Corn Steep Liquor (CSL) (\%) } & 1.3 & 1.5 & 2 & 2.5 & 2.7 \\
\hline
\end{tabular}


The yacon flour variable $\left(\mathrm{X}_{1}\right)$ did not have a statistically significant influence on either the linear or quadratic terms $(p>0.05)$, that is, the increase in the concentration, in the range studied, did not influence enzyme production (Table 5). However, Fig. 2a shows that the $7.0 \%$ concentration was the best condition and production decreased at concentrations below and above this value. The corn steep liquor had statistically significant effect on the linear term $(p<0.05)$, indicating that the increase in its concentration had positive influence and raised enzyme production (Fig. 2a). The interaction among the variables had a positive, but not significant, effect ( $p>0.05)$ (Table 5).
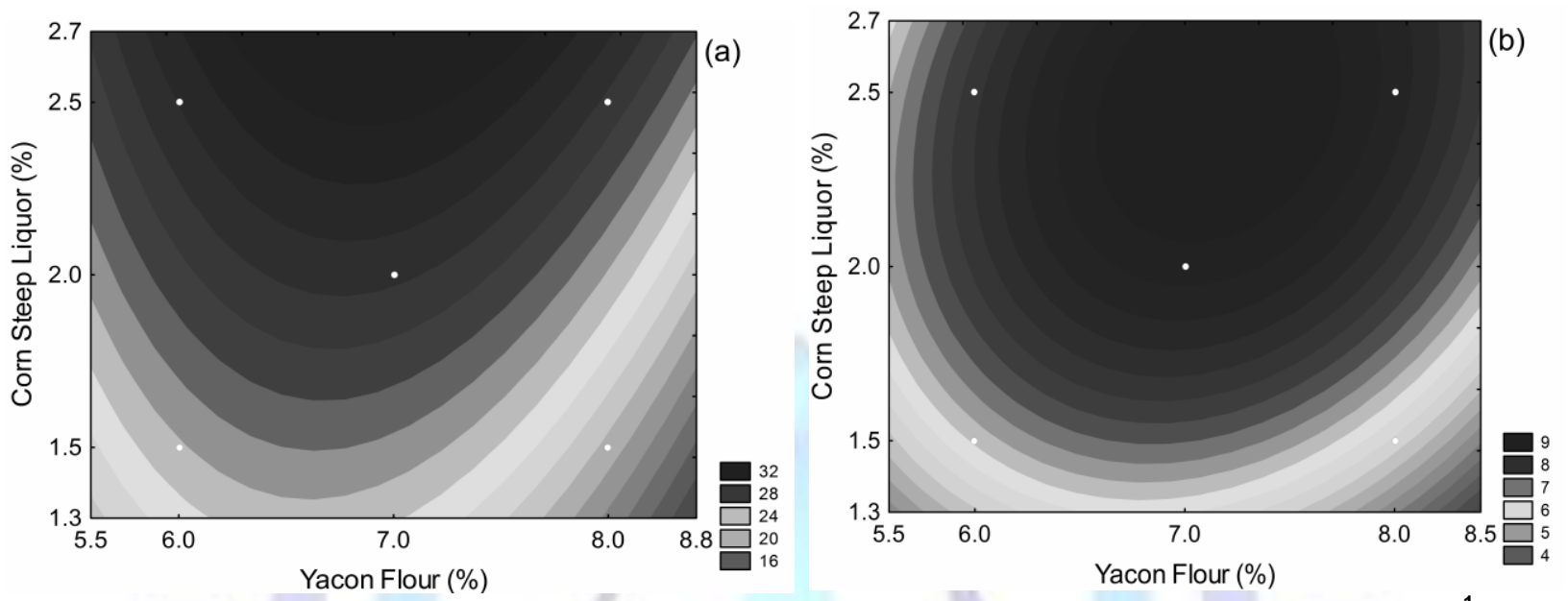

Fig 2. Contour plot from the model equation from experimental design 2 for inulinase production, U.ml ${ }^{-1}$ (a) and biomass production, $g . I^{-1}$ (b) by $K$. marxianus NRRL Y-7571 in submerged fermentation after 96 hours.

Table 5. Regression coefficient of inulinase production

\begin{tabular}{|l|c|c|c|c|}
\hline & $\begin{array}{c}\text { Regression } \\
\text { coefficient }\end{array}$ & Standard error & t(5) & P-value \\
\hline Mean & 28.23333 & 1.848020 & 15.27761 & 0.000022 \\
\hline Yacon flour (\%) (L) & -1.38226 & 1.848020 & -1.22143 & 0.276369 \\
\hline Yacon flour (\%) (Q) & -2.96042 & 1.346965 & -2.19784 & 0.079309 \\
\hline CSL (\%) (L) & 3.32754 & 1.131677 & 2.94036 & 0.032243 \\
\hline CSL (\%) (Q) & -0.21042 & 1.346965 & -0.15622 & 0.881975 \\
\hline Yacon flour x CSL & 0.72500 & 1.600432 & 0.45300 & 0.669527 \\
\hline L: Linear; Q: Quadratic & & & & \\
\hline
\end{tabular}

For biomass production, both yacon flour and corn steep liquor presented significant effects, with $P$-value $<0.05$ for the quadratic terms of $X_{1}$ and $X_{2}$ and the linear term of $X_{2}$, as shown by the coefficients of regression in Table 6 . Fig. $2 b$ shows that for biomass, the process could be optimized and the best culture conditions were obtained in run 8 and the central point (runs 9, 10 and 11 ), with $7.0 \%$ yacon flour and $2.0 \%-2.7 \%$ corn steep liquor.

The analysis of variance (ANOVA) showed that the model was statistically significant at $95 \%$ confidence level, because the $F$ value was 7.21 for enzyme production and 29.70 for biomass. The coefficients of correlation $\left(R^{2}\right)$ of 0.75534 for inulinase production showed a good correlation among the observed and predicted responses and the model explained almost $76.0 \%$ of the results. For biomass, the $\mathrm{R}^{2}$ of 0.92699 suggested that the generated model explained about $93.0 \%$ of the total variation of the results, which is an excellent representation of the process by the model. 
Table 6. Regression coefficient of biomass production

\begin{tabular}{|l|c|c|c|c|}
\hline & $\begin{array}{c}\text { Regression } \\
\text { coefficient }\end{array}$ & Standard error & $\mathbf{t}(5)$ & P-value \\
\hline Mean & 8.62333 & 0.282172 & 30.56060 & 0.000001 \\
\hline Yacon flour (\%) (L) & 0.02906 & 0.172794 & 0.16819 & 0.873026 \\
\hline Yacon flour (\%) (Q) & -1.02792 & 0.205666 & -4.99799 & 0.004112 \\
\hline CSL (\%) (L) & 1.01489 & 0.172794 & 5.87338 & 0.002031 \\
\hline CSL (\%) (Q) & -0.58542 & 0.205666 & -2.84644 & 0.035974 \\
\hline Yacon flour x CSL & 0.33750 & 0.244368 & 1.38111 & 0.225781 \\
\hline L: Linear; Q: Quadratic & & & & \\
\hline
\end{tabular}

The mathematical models that relate inulinase $(Y)$ and biomass $\left(Y^{\prime}\right)$ production in function of the yacon flour $\left(X_{1}\right)$ and corn steep liquor $\left(\mathrm{X}_{2}\right)$ variables can be expressed by equations 2 and 3 , respectively, and these models can be used to predict inulinase and biomass productions within the limits of the experimental factors.

\section{DISCUSSION}

$$
\begin{aligned}
& Y=28.23-1.38 X_{1}-2.96 X_{1}{ }^{2}+1.02 X_{2}-0.59 X_{2}{ }^{2}+0.34 \cdot X_{1} \cdot X_{2} \\
& Y^{\prime}=8.62+0.03 X_{1}-1.03 X_{1}{ }^{2}+1.01 X_{2}-0.59 X_{2}{ }^{2}+0.34 X_{1} \cdot X_{2}
\end{aligned}
$$

It is well established in the literature that carbon and nitrogen sources are some of the factors that most influence fermentation processes and can cause great variability in results, especially when dealing with complex substrates such as plant extracts or agro-industrial byproducts. However, in an endeavor to reduce process costs, agro-industrial substrates are increasingly studied and the establishment of their ideal concentration in the culture medium has been the objective of much research in this area. Interest has grown in inulin, a polyfructans widespread among plants as source of reserve energy, because it is a relatively cheap and abundant substrate for fructose syrup and ethanol [8]. The plant substrates that contain inulin most described in the literature as culture medium for the fermentation processes are Jerusalem artichoke $[6,21,37]$, chicory root $[22,26]$ and dahlia tubers [38]. Yacon has only recently been studied as a fermentation substrate (39). Regarding yacon flour, its use has been described only in food formulation, such as cakes [40-41].

Naturally, the ideal is to obtain high yields of the metabolite of interest at the lowest possible substrate concentration. In this case, yacon flour and corn steep liquor presented good results, because the best biomass and inulinase productions were obtained at relatively low concentrations of these carbon and nitrogen sources, $7.0 \%$ and $2.7 \%$, respectively. This is a common characteristic in studies reporting microbial inulinase production and most describe the best production at low concentrations of the carbon source: $4 \%$ chicory root extract [42], $3 \%$ Jerusalem artichoke [37], $2.5 \%$ to $6.5 \%$ buckwheat [43]. This occurs because inulinase is an enzyme that presents catabolic repression in the presence of excess substrate, especially the carbon source [44]. Furthermore, the complex composition of agroindustrial substrates can cause a negative effect due to the increase in the concentration of some of their constituents [43]. Regarding corn steep liquor, different concentrations are found in the literature, ranging from $0.3 \%$ to $20 \%$, or even more $[29,45,46,47,48]$ showing that the response to this substrate depends mainly on the microorganism used and should be adjusted to the metabolic needs of each one.

The optimum temperature and optimum pH profile for inulinase of $K$. marxianus NRRL Y-7571 produced with yacon flour were observed at $60^{\circ} \mathrm{C}$ and $\mathrm{pH} 4.0$, respectively. Other authors have also reported similar optimum $\mathrm{pH}$ and temperature values for $K$. marxianus [38, 39, 46, 49], but inulinases from other fungi species have also presented similar biochemical characteristics $[17,26,50]$. This characteristic is very interesting for the industrial sector, because acid $\mathrm{pH}$ and higher temperatures decrease the risk of contamination [16].

The thermostability tests showed that inulinase maintained more than $95 \%$ of its activity for three hours at $45^{\circ} \mathrm{C}$ and about $90 \%$ for four hours at $50^{\circ} \mathrm{C}$. These results indicated certain thermostability in this enzyme, which is a very desirable characteristic for application in biotechnological processes. However, the enzyme was quickly inactivated at $60^{\circ} \mathrm{C}$, a performance commonly described for most of the microbial inulinases [18]. According to Zhou and Chen [51], temperature acts on the enzyme activity in the same way as an enzymatic catalyze until it reaches the optimum value, above which activity decreases due to denaturation. 


\section{CONCLUSIONS}

Yacon flour was a viable substrate for application in fermentation processes, not only because of the good inulinase and biomass yields obtained in this work, but also because it presented low variability. The results obtained showed that the increase on yacon flour concentration, in the range studied, influenced positively up to the $7.0 \%$ limit, and this was the best concentration for production of both biomass and inulinase. This result is very desirable because there is no need for a great quantity of substrate to obtain the enzyme, which helps reduce the process costs. Similarly, corn steep liquor also presented the best results at low concentrations, and was shown to be a good nitrogen source for inulinase production. This characteristic is very interesting, because this substrate is cheaper compared to other nitrogen sources such as peptone and yeast extract. Central Composite Design (CCD) was very useful to establish the best substrate concentration and made it possible to optimize the process with a small number of experiments. In addition, with surface response analysis the interaction among variables could be visualized, giving a more complete view of the microorganism performance during the process.

\section{ACKNOWLEDGEMENT}

The authors are grateful for Coordination of Improvement of Higher Education Personnel (CAPES) and Foundation for Research Support of the State of Bahia (FAPESB) for financial support.

\section{REFERENCES}

[1] Campos, D., Betalleluz-Pallardel, I., Chirinos, R., Aguilar-Galvez, A., Noratto, G. and Pedreschi, R. 2012. Prebiotic effects of yacon (Smallanthus sonchifolius Poepp. \& Endl), a source of fructooligosaccharides and phenolic compounds with antioxidant activity, Food. Chem. 135: 1592-1599.

[2] Hauly, C.O.M. and Moscatto, J.A. 2002. Inulin and oligofructosis: a review about functional properties, prebiotic effects and importance for food industry, Semina: Ex. Tech., 23: 105-118.

[3] Roberfroid, M.B. 2005. Introducing inulin-type fructans, Brit. J. Nutr. 93: S13-S25.

[4] Roberfroid, M. 2007. Inulin-type fructans: functional food ingredients, J. Nutr. 137: 2493S-2502S.

[5] Bonciu C.N. and Bahrim, G. 2011. Inulinases-a versatile tool for biotechnology, Innov. Rom. Food Biotechnol. 9: 111.

[6] Chi, Z.M., Zhang, T., Cao, T.S., Liu, X.Y., Cui, X. and Zhao, C.H. 2011. Biotechnological potential of inulin for bioprocess, Bioresour. Technol. 102: 4295-4303.

[7] Lim, S.H., Ryu, J.M., Lee, H., Jeon, J.H., Sok, D.E. and Choi, E.S. 2011. Ethanol fermentation from Jerusalem artichoke powder using Saccharomyces cerevisiae KCCM50549 without pretreatment for inulin hydrolysis, Bioresour. Technol. 102: 2109-2111.

[8] Yuan, W.J., Zhao, X.Q., Ge, X.M and Bai, F.W. 2008. Ethanol fermentation with Kluyveromyces marxianus from Jerusalem artichoke grown in salina and irrigated with a mixture of seawater and freshwater, J. Appl. Microbiol. 105: 2076-2083.

[9] Lachman, J., Havrland, B., Fernández, E.C., and Dudjak, J. 2004. Saccharides of yacon [Smallanthus sonchifolius (Poepp. et Endl.) H. Robinson] tubers and rhizomes and factors affecting their content. Plant Soil Environ, 50: $383-$ 390.

[10] Seminario, J., Valdemarra, M. and Manrique, L. 2003. El yacon: fundamentos para el aprovechamiento de um recurso promisorio. Centro Internacional de La papa (CIP), Universidad Nacional de Cajamarca, Agencia Suiza para el Desarrollo y la Coperacion (COSUDE), Lima, PE, Pp.60.

[11] Vilhena, S.M.C., Câmara, F.L.A. and Kakihara, S.T. 2000. O cultivo de yacon no Brasil, Hortic. Bras. $18:$ 5-8.

[12] Santana, I. and Cardoso, M.H. 2008. Raiz tuberosa de yacon (Smallanthus sonchifolius): potencialidade de cultivo, aspectos tecnológicos e nutricionais, Cienc. Rural. 38: 898-905.

[13] Hermman, M., Freire, I and Pazos, C. 1999. Compositional diversity of the yacon storage root. In: Impact on a changing world: Program Report 1997-98, International Potato Center (CIP), Lima, Peru, Pp. 425-432.

[14] Ettalibi, M. and Baratti, J.C. 2001. Sucrose hydrolysis by thermostable immobilized inulinases from Aspergillus ficuum, Enzyme Microbial Technol. 2: 596- 601.

[15] Pessoni, R.A.B., Figueiredo-Ribeiro, R.C.L. and Braga, M.R. 1999. Extracellular inulinases from Penicillium janczewskii, a fungus isolated from the rhizosphere of Vernonia herbacea (Asteraceae), J. Appl. Microbiol. 87: 141147.

[16] Vandamme, E.J. and Derycke, D.G. 1983. Microbial inulinases: fermentation process, properties, and applications, Adv. App. Microbiol. 29: 139-176.

[17] Dinarvand, M., Ariff, A.B., Moeini, H., Masomian, M., Mousavi, S.S., Nahavandi, R.and Mustafa, S. 2012. Effect of extrinsic and intrinsic parameters on inulinase production by Aspergillus niger ATCC 20611, Electron. J. Biotechnol. 15: 1-9. 
[18] Singh, P. and Gill, P. 2006. Production of inulinases: recent advances. Food Technol. Biotechnol, 44:151-162.

[19] Cho, Y.J., and Yun, J.W. 2002. Purification and characterization of an inulinase from Xanthomonas oryzae No. 5, Proc. Biochem. 37:1325-1331.

[20] Dilipkumar, M., Rajasimman, M. and Rajamohan, N. 2011. Optimization of inulinase production from garlic by Streptomyces sp. in solid state fermentation using statistical designs, Biotechnol. Res. Int. 2011: 1-7.

[21] Laowklom, N., Chantanaphan, R. and Pinphanichakarn, P. 2012. Production, purification and characterization of inulinase from a newly isolated Streptomyces sp. CP01, Nat. Resources. 3: 137-144.

[22] Kango,N. 2008. Production of inulinase using tap roots of dandelion (Taraxacum officinalle) by Aspergillus niger, J. Food Eng. 85:, 473-478.

[23] Mutanda, T., Wilheimi, B.S., and Whiteley, C.G. 2008. Response surface methodology: synthesis of inulooligosaccharides with an endoinulinase from Aspergillus niger, Enzyme Microbial Technol. 43: 362-368.

[24] Poorna, V. and Kulkarni, P.R. 1995. A study of inulinase in Aspegillus niger using fractional factorial design, Bioresour. Technol, 54: 315-320.

[25] Skowronek, M. and Fiedurek, J. 2003. Selection of biochemical mutants of Aspergillus niger resistant to some abiotic stresses with increased inulinase production, J. Appl. Microbiol. 95: 686-692.

[26] Trivedi, S., Divecha, J, and Shah, A. 2012. Optimization of inulinase production by a newly isolated Aspergillums tubingensis CR16 using low cost substrates, Carb. Pol. 90: 483- 490.

[27] Yu, X., Guo, N., Chi, Z., Gong, F., Sheng, J. and Chi, Z. 2009. Inulinase overproduction by a mutant of the marine yeast Pichia guilliermondii using surface response methodology and inulin hydrolysis, Biochem. Eng. J. 43: $266-271$.

[28] Seok-Hwan, L., Lee, H., Sok, D. and Choi, E. 2010. Recombinant production of an inulinase in a Saccharomyces cerevisiae gal80 strain, J. Microbiol. Biotechnol. 20: 1529-1533.

[29] Bender, J.P., Mazutti, M.A., Oliveria, D., Di Luccio, M. and Treichel, H. 2006. Inulinase Production by Kluyveromyces marxianus NRRL Y-7571 using solid state fermentation, Appl. Biochem. Biotechnol. 129-132: 951-958.

[30] Risso, F.V.A., Mazutti, M.A.H., Treichel, H., Costa, F., Maugeri Filho, F. and Rodrigues, M.I. 2012. Assessment of fructooligosaccharides production from sucrose in aqueous and aqueous-organic systems using immobilized inulinase from Kluyveromyces marxianus NRRL Y-7571, Ciênc. Tecnol. Aliment. 32: 245-24.

[31] Yuan, B.H.N, Sun, J. Wang, S.A. and Fu-Li, L. 2012. Purification and characterization of a novel extracellular inulinase from a new yeast species Candida kutaonensis sp. nov. KRF1T, Appl. Microbiol. Biotechnol. 96:, $1517-26$.

[32] Paula, F.C., Cazetta, M.L., Monti, R. and Contiero, J. 2008. Sucrose hydrolysis by gelatin-immobilized inulinase from Kluyveromyces marxianus var. bulgaricus. Food. Chem. 111: 691-695.

[33] Makino, Y., Treichel, H., Mazutti, M.A., Maugeri Filho, F. and Rodrigues, M.I. 2009. Inulinase bio-producing using agroindustrial residues: screening of microorganisms and process parameters optimization, J. Chem. Technol. Biotechnol. 84: 1056-1062.

[34] Rodrigues, M.I. and lemma, A.F. 2009. Planejamento de experimentos e otimização de processos: uma estratégia seqüencial de planejamentos. Casa do Pão de Queijo Editora, Campinas.

[35] Suzuki, H., Ozawa, T. and Maeda, H. 1988. Studies of water-insoluble yeast invertase, Agr. Biol. Chem. 30: 807812.

[36] Miller, G.L. 1959. Use of dinitrosalicylic acid reagent for determination of reducing sugar, Anal. Chem., 31: 426-428.

[37] Erdal, S., Canli, O. and Algur, F.O. 2011. Inulinase production by Geotrichum candidum using Jerusalem artichoke as sole carbon source, Rom. Biotechnol. Lett., 16: 6378-6383.

[38] Jain, S.C. and Jain, N.K. 2012. Production of inulinase from Kluyveromyces marxianus using dahlia tuber extract, Braz. J. Microbiol. 43: 62-69.

[39] Cazetta, M.L., Martins, P.M.M., Monti, R. and Contiero, J. 2005. Yacon (Polymnia sanchifolia) extract as a substrate to produce inulinase by Kluyveromyces marxianus var. bulgaricus, J. Food Eng. 66: 301-305.

[40] Moscatto, J.A., Prudêncio-Ferreira, S.H. and Hauly, M.C.O. 2004. Farinha de yacon e inulina como ingredientes na formulação de bolo de chocolate, Ciênc. Tecnol. Aliment. 24: 634-640.

[41] Rosa, C.S., Oliveira, V.R., Viera, V.B., Gressler, C. and Viega, S. 2009. Cake developed with Yacon flour, Cienc. Rural. 39: 1869-1872.

[42] Fawzi, E.M. 2011. Comparative study of two purified inulinases from thermophile thielavia terrestris NRRL 8126 and mesophile Aspergillus foetidus NRRL 337 grown on Cichorium intybus I, Braz. J. Microbiol. 42: 633-649. 
[43] Bonciu, C.N., Constantin, O. and Bahrim, G. 2012. Increase in extracellular inulinase production for a new isolated Rhizoctonia ssp. strain by using buckwheat (Fagopyrum esculentum) flour as a single carbon source, Lett. Appl. Microbiol. 55: 195-201.

[44] Parekh, S. and Margaritis, A. 1995. Inulinase ( $\beta$-fructofuranosidase) production by Kluyeromyces marxianus in batch culture, Appl. Microbiol. Biotechnol. 22: $446-448$.

[45] Corrêa, T.L.R., Stella, K.S., Moutinho, M.L.L. and Martins, M.A.M. 2011. Simultaneous a-amylase and protease production by the soil bacterium Bacillus sp. SMIA-2 under submerged culture using whey protein concentrate and corn steep liquor: compatibility of enzymes with commercial detergents, Ciênc. Tecnol. Aliment. 31: 843-84.

[46] Mazutti, M., Bender, J.P., Treichel, H. and Di Luccio, M. 2006. Optimization of inulinase production by solid-state fermentation using sugarcane bagasse as substrate, Enzyme Microbial. Technol. 39: 56-59.

[47] Mazutti, M., Ceni, G., Di Luccio, M and Treichel, H. 2007. Production of inulinase by solid-state fermentation: effect of process parameters on production and preliminary characterization of enzyme preparations, Bioprocess Biosyst. Eng. 30: 297-304.

[48] Sguarezi, C., Longo, C., Ceni, G., Boni, G., Silva, M.F., Di Luccio, M., Mazutti, M.A., Maugeri Filho, F., Rodrigues, M.I. and Treichel, H. 2009. Inulinase production by agro-industrial residues: optimization of pretreatment of substrates and production medium, Food Bioprocess Technol. 2: 409-414.

[49] Kushi, R.T., Monti, R. and Contiero, J. 2000. Production, purification and characterization of an extracelular inulinase from Kluyveromyces marxianus var. bulgaricus, J. Ind. Microbiol. Biotechnol. 25: 63-69.

[50] Guimarães, L.H.S., Terenzi, H.F., Polizeli, M.L. and Jorge, J.A. 2007. Production and characterization of a thermostable extracellular $\beta$-D-fructofuranosidase by Aspergillus ochraceus with agroindustrial residues as carbon source, Enzyme Microb. Technol. 42: 52-57.

[51] Zhou, Q.Z.K. and Chen, X.D. 2001. Effects of temperature and pH on the catalytic activity of the immobilized $\beta$ galactosidase from Kluyveromyces lactis, Bioch. Eng. J. 9: 33-40.

\section{Author' biography with Photo}

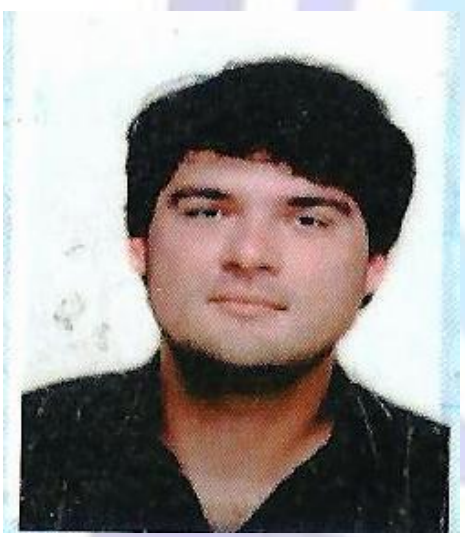

Leonardo de Amorim Sathler is graduated in Biological Sciences and completed his Msc in Agricultural Microbiology from Federal University of Recôncavo da Bahia, Brazil. His current interests are on the topics of fermentation, biotechnology, besides in the environmental and sustainability area. 